\title{
The effect of tea on iron and aluminium metabolism in the rat
}

\author{
BY SUSAN J. FAIRWEATHER-TAIT AND ZOE PIPER \\ AFRC Institute of Food Research, Colney Lane, Norwich, Norfolk NR4 $7 U A$ \\ AND S. JEMIL A. FATEMI AND GEOFFREY R. MOORE \\ School of Chemical Sciences, University of East Anglia, Norwich, Norfolk NR4 7TJ
}

(Received 13 March 1990 - Accepted 20 July 1990)

\begin{abstract}
Weanling male Wistar rats were fed for $28 \mathrm{~d}$ on a semi-synthetic diet containing normal $(38 \mu \mathrm{g} / \mathrm{g}$ ) or low $(9 \mu \mathrm{g} / \mathrm{g})$ levels of iron. They were given water or tea infusion ( $20 \mathrm{~g}$ leaves/1 water) to drink. Two further groups were given a normal- or low-Fe diet containing added tea leaves $(20 \mathrm{~g} / \mathrm{kg}$ diet $)$. At the end of the study period, all rats given the low-Fe diet were severely anaemic, as assessed by haemoglobin, packed cell volume and liver Fe. Those given tea or the diet with added tea leaves showed a greater degree of Fe depletion. The blood and liver aluminium levels were not increased as a result of consuming tea or tea leaves, despite the higher $\mathrm{Al}$ intakes. Fe deficiency per se had no effect on $\mathrm{Al}$ absorption or retention from tea. It was concluded that the $\mathrm{Al}$ in tea was very poorly absorbed but that tea, either in the form of an infusion or as tea leaves, had an adverse effect on Fe status.
\end{abstract}

Iron metabolism: Aluminium metabolism: Tea : Rat

Aluminium is the third most abundant element in nature, after oxygen and silicon, yet it is probably not an essential nutrient. Although very little is known about its biological effects in the human body, there have been suggestions of a link between $\mathrm{Al}$ and Alzheimer's disease (Candy et al. 1986). However, interest in Al as a potentially toxic material increased dramatically during 1989 following the accidental contamination of drinking water with $\mathrm{Al}$ in Cornwall, and reports in the literature that some baby formulas made from soya-bean milk contain up to ten times more Al than breast milk (Koo et al. 1988; Ministry of Agriculture, Fisheries and Food, personal communication). In the debate that ensued it became clear that very little is known about $\mathrm{Al}$ absorption from the diet and it was this paucity of information that gave rise to the present study. Because there are no stable isotopes of $\mathrm{Al}$ and radio-isotopes are not readily available, work on $\mathrm{Al}$ metabolism is difficult to perform, particularly in human subjects, and therefore we have used rats for our study.

Tea is a rich source of $\mathrm{Al}$, the tea plant actively taking up $\mathrm{Al}$ from the soil and storing it in its leaves (Chenery, 1955). However, it is not known to what extent the $\mathrm{Al}$ in tea is absorbed and retained by the body. The present study was therefore undertaken in rats to assess the bioavailability of $\mathrm{Al}$ from tea and tea leaves. In addition, because the absorption of several inorganic elements is increased in iron-deficient states (Forth \& Rummel, 1973), groups of rats were given low-Fe diets in conjunction with tea or tea leaves in order to investigate the effects of $\mathrm{Fe}$ deficiency on $\mathrm{Al}$ metabolism. The tannins in tea render any $\mathrm{Fe}$ consumed at the same time less available for absorption (Disler et al. 1975). Therefore, the effects of tea on Fe status were also determined.

MATERIALS AND METHODS

Six groups of fifteen weanling male Wistar rats were individually caged in stainless steel and plastic cages with gridded bottoms. Three groups were given normal- (38 $\mu \mathrm{g} \mathrm{Fe} / \mathrm{g}$ ) and 
Table 1. Composition of the normal-iron semi-synthetic diet given to rats $(\mathrm{g} / \mathrm{kg}$ diet $)$

$\begin{array}{lll}\text { Maize starch } & 309 \\ \text { Sucrose } & 309 \\ \text { Casein } & 200 \\ \text { Solka floc } & 40 \\ & \text { Maize oil } & 80 \\ & \text { Mineral mix* } & 40 \\ & \text { Vitamin mix } & =-\cdots \\ & \text { Methionine } & 20 \\ & \end{array}$

* Contained (g/kg diet): $\mathrm{CaHPO}_{4} 13 \cdot 0, \mathrm{CaCO}_{3} 8 \cdot 2, \mathrm{Na}_{4} \mathrm{HPO}_{4} 7 \cdot 4, \mathrm{KCl} 7 \cdot 03, \mathrm{MgSO}_{4}, \mathrm{H}_{2} \mathrm{O} 4 \cdot 0, \mathrm{MnSO}_{4}, \mathrm{H}_{2} \mathrm{O}$ $0 \cdot 180, \mathrm{FeSO}_{4} .7 \mathrm{H}_{2} \mathrm{O} 0 \cdot 144, \mathrm{ZnCO}_{3} 0 \cdot 100, \mathrm{CuSO}_{4} .5 \mathrm{H}_{2} \mathrm{O} 0 \cdot 023, \mathrm{~K}^{2} \mathrm{O}_{3} 0 \cdot 001$.

** Contained (mg/kg diet) : nicotinic acid 60, cyanocobalamin in mannitol (Glaxo) 50, calcium-D-pantothenate 40 , thiamin hydrochloride 10 , riboflavin 10 , pyridoxine 10 , pteroylomonoglutamic acid 10 , D-biotin 1 , vitamin $\mathrm{K}_{1}$ (in lactose) 2, Rovimix E-50 150 (containing $75 \mathrm{mg}$ DL- $\alpha$-tocopheryl acetate), Rovimix A-500 25 (containing 3.75 mg retinol), Rovimix $\mathrm{D}_{3}-50015$ (containing $188 \mu \mathrm{g}$ cholecalciferol; all Rovimix products from Roche, North Dunstable, Bedfordshire), choline bitartrate 1800, starch (bulking agent) 17817.

Table 2. Operating conditions used for aluminium determination by graphite-furnace atomic absorption spectrophotometry

$\begin{array}{rrrr} & \text { Temperature }\left(^{\circ}\right) & \text { Ramp(s) } & \text { Hold(s) } \\ \text { Step } 1 & 90 & 8 & 10 \\ 2 & 140 & 8 & 30 \\ 3 & 550 & 7 & 30 \\ 4 & 1400 & 4 & 20 \\ 5 & 2500 & 0 & 3 \\ 6 & 3000 & 0 & 2\end{array}$

Sample volume $20 \mu \mathrm{l}$; wavelength 309-3; Ballysound correction (deuterium); signal mode = peak height; autosampler; argon gas; pyrolytic-coated graphite tubes.

three low-Fe $(9 \mu \mathrm{g} \mathrm{Fe} / \mathrm{g})$ semi-synthetic diets, made by omitting the ferrous sulphate from the mineral mix; the composition of the normal-Fe diet is shown in Table 1. At each Fe level, one group was given distilled water to drink ad lib., the second group an infusion of tea (PG Tips, Brooke Bond, Croydon, Surrey) and the third group tea leaves (PG Tips) incorporated into the diet $(20 \mathrm{~g}$ leaves $/ \mathrm{kg}$ diet, replacing $10 \mathrm{~g}$ starch and $10 \mathrm{~g}$ sucrose). The tea infusion was made three times/week by adding 1 litre boiling distilled water to $20 \mathrm{~g}$ tea leaves, stirring, leaving to stand for $10 \mathrm{~min}$ and then filtering through fine nylon gauze. All intakes of food and drink were measured daily, and the animals weighed at regular intervals.

After 4 weeks, the animals were killed by intraperitoneal administration of a lethal dose of sodium pentobarbitone anaesthetic $(1 \mathrm{ml}$ Euthatal $(20 \mathrm{mg} / \mathrm{ml})$; May \& Baker Ltd, Dagenham, Essex), blood taken by cardiac puncture, the liver removed, rinsed in saline $(9 \mathrm{~g}$ sodium chloride/1), blotted dry, freeze-dried, and homogenized using a pestle and mortar. The following analyses were performed: $(a)$ blood haemoglobin $(\mathrm{Hb}$, cyanomethaemoglobin method), (b) blood packed cell volume (PVC, microhaematocrit method), (c) liver Fe (flame atomic absorption spectrophotometry (AAS), PU9000 Pye Unicam, Cambridge), (d) liver Al (graphite-furnace AAS, SP9, Pye Unicam, Cambridge, operating conditions described in Table 2), (e) blood Al (as for the liver determination), and $(f)$ food and drink Fe (flame AAS) and Al (graphite furnace AAS) concentrations.

The samples for flame AAS were heated to $480^{\circ}$ for $48 \mathrm{~h}$ in silica crucibles, the ash taken 
up in hot hydrochloric acid (Analar) and the solution made up to an appropriate volume with Analytical grade (AR) water (Fisons). Liver ( $0.15 \mathrm{~g}$ dried material) and food $(0.5 \mathrm{~g}$ diet) samples for $\mathrm{Al}$ analysis by graphite furnace were digested with $3 \mathrm{ml}$ concentrated nitric acid (aristar) in PTFE-lined stainless steel pressure digestion vessels (Cowie Scientific Ltd, Middlesbrough, Cleveland). The lids on the vessels were screwed down and they were placed in an oven at $125^{\circ}$ for $3 \mathrm{~h}$. After cooling, the top was removed and the $\mathrm{HNO}_{3}$ gradually evaporated on a hot plate. Before complete drying, the solution was transferred to a $20 \mathrm{ml}$ volumetric flask and made up to volume with water (AR).

The blood samples, which had been stored at $-18^{\circ}$, were prepared for analysis by adding $0.5 \mathrm{ml}$ blood to an acid-washed, EDTA $(100 \mathrm{~g} / \mathrm{l})$-washed polyethylene centrifuge tube and the proteins precipitated by the procedure of Brown et al. (1984). The solution was mixed on a Vortex mixer at medium speed and $0.5 \mathrm{ml}$ water (AR) and $50 \mu \mathrm{l}$ concentrated $\mathrm{HNO}_{3}$ (aristar) were added whilst mixing for $1 \mathrm{~min}$. The solution was heated for $10 \mathrm{~min}$ at $70^{\circ}$ in a water-bath, mixed again for $20 \mathrm{~s}$, and then centrifuged for $10 \mathrm{~min}$ at $2000 \mathrm{~g}$. The supernatant fraction was pipetted into a Teflon sampling cup and the autosampler used for injection. Tea infusions were analysed directly by graphite-furnace AAS (Fairweather-Tait et al. 1987). Al standards were prepared by appropriate dilution with water (AR) from a stock solution of aluminium nitrate (BDH, Poole, Dorset), the calibration curve being linear from 0 to $30 \mu \mathrm{g} \mathrm{Al} / 1$.

\section{Statistical treatment}

Results for all analyses were subjected to two-way analysis of variance (AOV) with two variables: level of dietary Fe (low, normal) and type of diet (water, tea, diet with tea leaves). Because the number in the groups differed, the standard error of the difference between means (SED) was calculated from

$$
\sqrt{\text { residual mean square (RMS) } /\left(1 / n_{1}+1 / n_{2}\right)}
$$

for each pair of groups, and approximate $t$ tests performed, where $t=$ (mean 1 -mean 2)/SED. Regression analysis was performed on $\mathrm{Al}$ intakes and liver Al levels. All analyses were carried out using GENSTAT programs (Payne et al. 1987).

\section{RESULTS}

There were no significant differences between the groups in the initial body-weights of the rats (mean 70 (SD 7) g), but at the end of the experiment, those given the low-Fe diet weighed significantly less $(P<0.001$, Table 3 ), with lower dry liver weights (Table 4$)$. Food intake was reduced in groups given the low-Fe diet, and the food conversion efficiency was slightly reduced (from 0.37 to $0.32 \mathrm{~g}$ weight gained/g food consumed). There was also an effect of dietary treatment on food intake $(P<0.01)$ whereby animals given water consumed more food than those given tea to drink. Al intakes are given in Table 3 , the lowest being in the group given low-Fe diet and water $(55 \mu \mathrm{g} / \mathrm{d})$, and highest in the group given normal-Fe diet containing tea leaves $(813 \mu \mathrm{g} / \mathrm{d})$.

The Fe concentration of the diet had a significant effect $(P<0.001)$ on Fe status, as assessed by liver $\mathrm{Fe}$, blood $\mathrm{Hb}$ and PCV (Table 4), whereby animals given the low-Fe diet were severely anaemic. Fe depletion was more marked in groups consuming the diet with added tea leaves or drinking the tea infusion than in the controls.

There was no effect of dietary treatment on blood Al concentrations (Table 5). Liver Al concentrations were highest in the group fed on the low-Fe diet containing tea leaves, but since the liver weights and food intakes were significantly different between the low-Fe and normal-Fe groups, total liver $\mathrm{Al}$ is probably a more valid comparison. Two-way $\mathrm{AOV}$ 


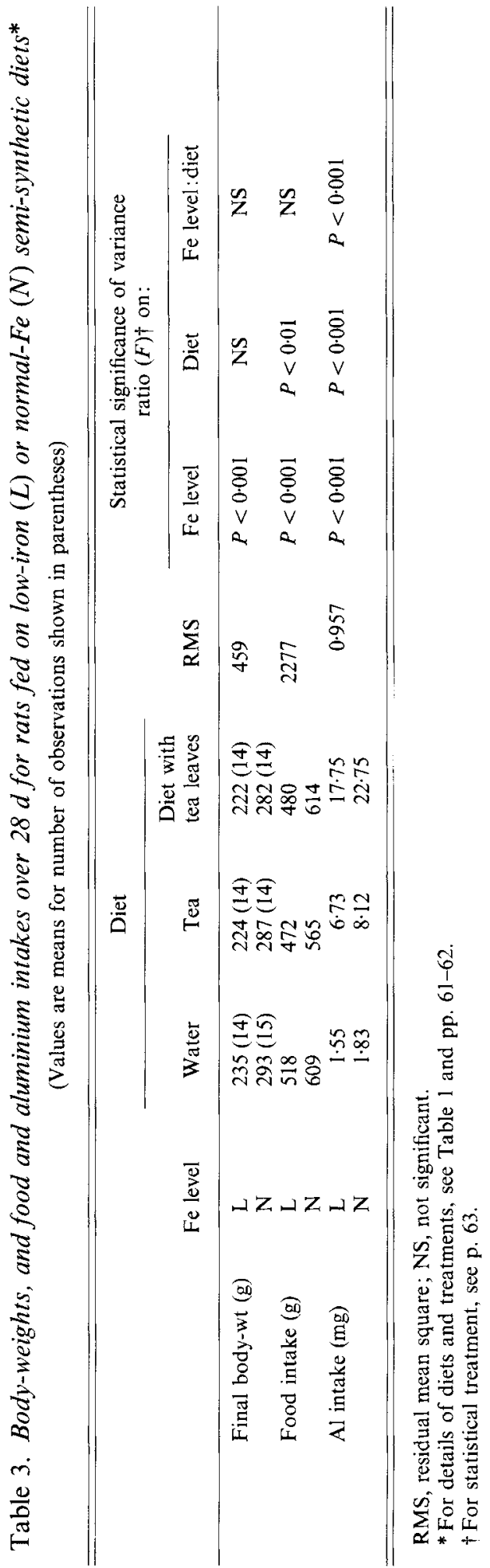


EFFECT OF TEA ON IRON AND ALUMINIUM METABOLISM

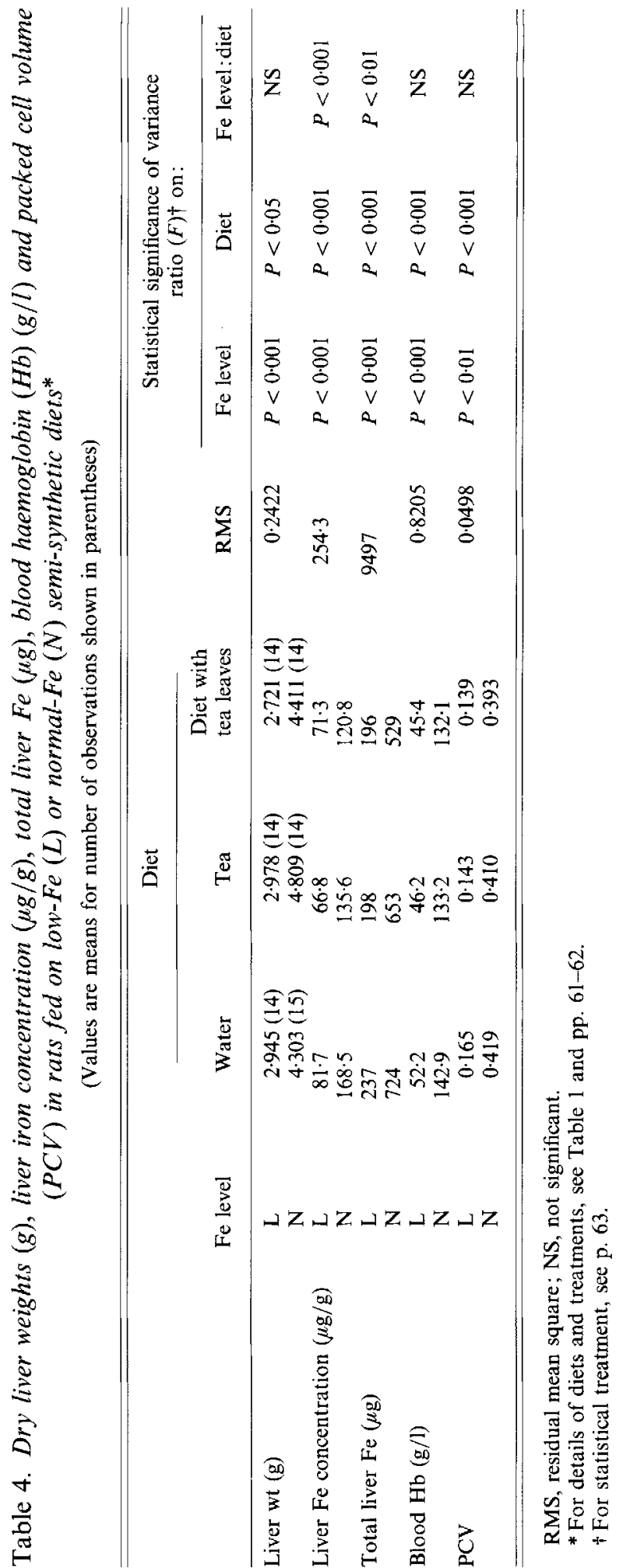




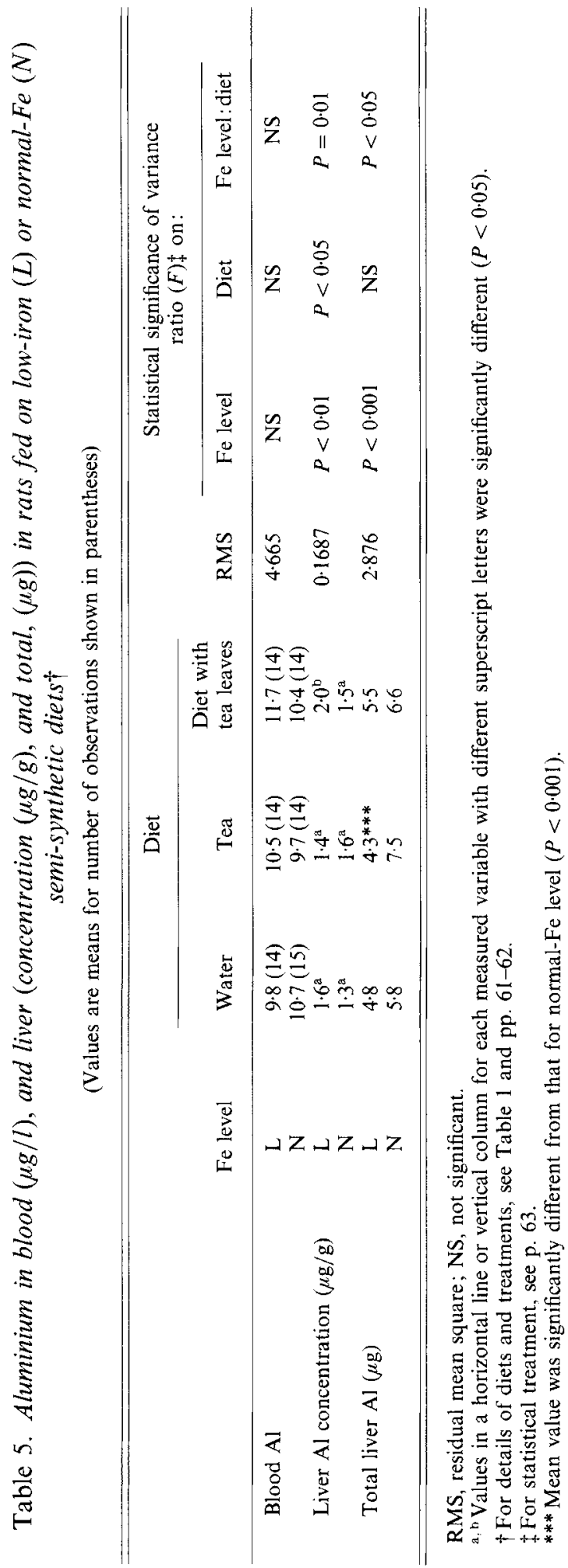


showed no effect of tea or tea leaves on total Al levels. However, the Fe level significantly influenced total liver $\mathrm{Al}$ content which was higher in the normal-Fe groups for each diet. This was significant for the group given tea to drink $(P<0 \cdot 001)$. Although there was a significant relationship $(R 0.22, P<0.05)$ between $\mathrm{Al}$ intake over the experimental period and liver $\mathrm{Al}$ levels (expressed as totals or concentrations), the regression analysis showed that only a very small percentage of the variance was accounted for $(<5 \%)$. It would therefore appear that the animals accumulated $\mathrm{Al}$ in their livers in relation to tissue growth, but that a 14-fold difference in $\mathrm{Al}$ intake did not affect the $\mathrm{Al}$ content of the liver.

\section{DISCUSSION}

The adverse effect of tea on Fe bioavailability has been known for some time (Disler et al. 1975), and the results of the present study confirm that long-term ingestion of tea impaired Fe status. Fe-deficient rats increase their efficiency of Fe absorption (Fairweather-Tait \& Wright, 1987) but not enough in the present study to overcome the inhibitory effects of tea and tea leaves, the magnitude of which was similar at both levels of dietary Fe. Assuming that the observed effects were entirely due to the tannin, the results demonstrated that tannin need not be ingested as a solution for inhibition of $\mathrm{Fe}$ absorption to occur in tea (and presumably fruits, vegetables and cereals as well), and suggests that the tannin is at least partially solubilized in the gastrointestinal tract.

Interactions between $\mathrm{Al}$ and $\mathrm{Fe}$ have been reported, although results are conflicting (Greger, 1988). Modest Al accumulation, as found in dialysis patients, has a pronounced inhibitory effect on $\mathrm{Hb}$ synthesis which responds well to desferrioxamine therapy (Altmann et al. 1988). It is not clear whether or not $\mathrm{Al}$ interferes with Fe absorption or subsequent metabolism, or both, but it may well be that $\mathrm{Al}$ absorption takes place along pathways for essential metals. If this is the case, Fe deficiency could result in increased absorption, as seen with manganese, cobalt and lead (Bothwell et al. 1979). However, results of the present study showed no effect of Fe deficiency on blood or liver Al levels. The selection of the liver for analysis was based on the results of a study in which rats were fed high amounts of $\mathrm{Al}$ (Ondreicka et al. 1966) and the liver, testes and bones had the most pronounced accumulation of $\mathrm{Al}$. There have been some reports in the literature suggesting that $\mathrm{Al}$ from aluminium chloride is accumulated in brain ferritin but not liver ferritin (Fleming \& Joshi, 1987). However, the work is controversial and since the general consensus is that liver $\mathrm{Al}$ levels reflect dietary intakes, the liver was selected for analysis rather than the brain. The values obtained for blood $\mathrm{Al}(9 \cdot 7-11 \cdot 7 \mu \mathrm{g} / 1)$ agree with those of D'Haese et al. (1985) who found a mean of 12.1 (SD 1.5$) \mu \mathrm{g} / 1$ in ten human subjects.

Tea is one of the most commonly consumed dietary sources of $\mathrm{Al}$, containing in the region of $4 \mathrm{mg} \mathrm{Al} / 1$ (Fairweather-Tait et al. 1987). Yet, consuming tea as the only source of liquid for a period of $28 \mathrm{~d}$ appeared to have no effect on Al accumulation in the body of growing rats. Assuming that man's lifespan is approximately 30 times that of a rat, a $28 \mathrm{~d}$ period in the rat's life is equivalent to 2.5 years in man. In the groups fed on normal-Fe diets the intakes of $\mathrm{Al}$ during the period of study was $1.83,8 \cdot 12$ and $22.75 \mathrm{mg}$ in rats given water, tea or diet with tea leaves respectively. Mean total liver Al in the groups were $5 \cdot 8$, 7.5 and $6.6 \mu \mathrm{g}$ respectively, three orders of magnitude less than the diet. Assuming that the liver is a sensitive indicator of absorbed $\mathrm{Al}$ then it must be inferred from the results of the present study that very little, if any, of the $\mathrm{Al}$ in either tea infusion or tea leaves was retained in the body. One explanation for this may be the high fluoride content of tea which has been reported to increase $\mathrm{Al}$ excretion in the urine and faeces of rats, thereby decreasing body retention (Ondreicka et al. 1971). However, the lack of difference in blood Al would indicate that the $\mathrm{Al}$ in tea was not available for absorption, even in Fe deficiency when the efficiency of absorption of many inorganic elements is raised. 
The authors would like to thank Mrs J. Cooke and Dr S. Southon for animal care, Mr A. J. A. Wright for assistance with the haematological measurements, Mr T. E. Fox for help with the GENSTAT programs, and $\mathrm{Mr} \mathrm{M}$. Baxter for advice on Al determination by ETA AAS.

\section{REFERENCES}

Altmann, P., Marsh, F., Plowman, D. \& Cunningham, J. (1988). Aluminium chelation therapy in dialysis patients: evidence for inhibition of haemoglobin synthesis by low levels of aluminium. Lancet $\mathbf{i}, 1012-1015$.

Bothwell, T. H., Charlton, R. W., Cook, J. D. \& Finch, C. A. (1979). Iron Metabolism in Man, p. 273. London: Blackwell Scientific.

Brown, S., Bertholf, R. L., Wills, M. R. \& Savory, J. (1984). Electrothermal spectrometric determination of aluminium in serum with a new technique for protein precipitation. Clinical Chemistry 30, 1216-1218.

Candy, J. M., Klinowski, J., Perry, R. H., Perry, E. K., Fairburn, A., Oakley, A. E., Carpenter, T. A., Atack, J. R., Blessed, G. \& Edwardson, J. A. (1986). Aluminosilicates and senile plaque formation in Alzheimer's disease. Lancet i, 354-357.

Chenery, E. M. (1955). A preliminary study of aluminium and the tea bush. Plant and Soil 6, 174-200.

D'Haese, P. C., Van de Vyver, F. L., De Wolff, F. A. \& De Broe, M. E. (1985). Measurement of aluminium in serum, blood, urine, and tissues of chronic hemodialyzed patients by use of electrothermal atomic absorption spectrometry. Clinical Chemistry 31, 24-29.

Disler, P. B., Lynch, S. R., Charlton, R. W., Torrance, J. D. \& Bothwell, T. H. (1975). The effect of tea on iron absorption. Gut 16, 193-200.

Fairweather-Tait, S. J., Faulks, R. M., Fatemi, S. Jemil A. \& Moore, G. R. (1987). Aluminium in the diet. Human Nutrition: Food Sciences and Nutrition 41F, 183-192.

Fairweather-Tait, S. J. \& Wright, A. J. A. (1987). The importance of status and previous diet of animals on the estimation of bioavailability of different forms of metallic elements: studies on Fe. Toxicological and Environmental Chemistry 13, 223-238.

Fleming, J. \& Joshi, J. G. (1987). Ferritin: isolation of aluminium-ferritin complex from brain. Proceedings of the National Academy of Sciences, USA 84, 7866-7870.

Forth, W. \& Rummel, W. (1973). Iron absorption. Physiological Reviews 53, 724-792.

Greger, J. L. (1988). Tin and aluminium. In Trace Minerals in Foods, p. 307 [K. T. Smith, editor]. New York: Marcel Dekker.

Koo, W. W. K., Kaplan, L. A. \& Krug-Wispe, S. K. (1988). Aluminium contamination of infant formulas. Journal of Parenteral and Enteral Nutrition 12, 170-173.

Ondreicka, R., Ginter, E. \& Kortus, J. (1966). Chronic toxicity of aluminium in rats and mice and its effects on phosphorus metabolism. British Journal of Industrial Medicine 23, 305-312.

Ondreicka, R., Kortus, R. \& Ginter, E. (1971). Aluminium, its absorption, distribution, and effects on phosphorus metabolism. In Intestinal Absorption of Metal Ions, Trace Elements and Radionuclides, p. 297 [S. C. Skoryna and D. Waldron-Edward, editors]. Oxford: Pergamon Press.

Payne, R. W., Lane, P. W., Ainsley, A. E., Bicknell, K. E., Digby, P. G. N., Harding, S. A., Leech, P. K., Simpson, H. R., Todd, A. D., Verner, P. J., White, R. P., Gower, J. C., Tunnicliffe Wilson, G. \& Paterson, L. J. (1987). Genstat 5 Reference Manual. Oxford: Clarendon Press. 